\title{
Researchon Flexural Behaviourof Composite Beams
}

\author{
S.Gowtham, R. Mercy Shanthi, M.Jemimahcarmichael
}

\begin{abstract}
Concrete is the most used man-made material in the world, with approximately three tons used per annum per individual. Concrete is consumed twice as much as all other construction around the world including wood, steel, plastic, and aluminum. However, the material is used so widely that world cement production now contributes 5 percent of annual global $\mathrm{CO} 2$ production. Thus, the idea of reducing the amount of concrete in structures becomes attractive. A new concretecomposite beam with high mechanical performances to weight ratio is developed in this study. By constructing a hollow section in the reinforced concrete elements, a smaller quantity of concrete would be utilized. Hollow concrete sections are commonly used but their construction tends to complicate the setting up stage and increase the cost. In this work, investigation carried out on the strength of hollow reinforced concrete beams produced by the insertion of a bamboo tube, plastic and steel tube during construction is investigated. An experimental investigation is carried out on composite beams under bending loads until failure to evaluate the flexural capacity and the corresponding failure mechanisms. By the experimental method the specimens were tested for flexure and their results are compared.
\end{abstract}

Index Terms-Concrete Composite Beam, Hollow Section, Bamboo Tube, PVC Tube, Steel Tube.

\section{INTRODUCTION}

Concrete is a widely used construction material for its various advantages such as low cost, availability, fire resistance etc., but it cannot be used alone everywhere because of its low tensile strength. So generally steel is used to reinforce the concrete. Though steel has a high tensile strength to complement the low tensile strength of concrete, use of steel should be limited since it is very costly and also so much energy consuming in manufacturing process. Most buildings are built using such materials as steel reinforced concrete and structural steel. Specifically, concrete is a high quality and economical material with its ability to support fire and earthquake defence in buildings constructed in developed and developing countries. One of the significant faults of concrete is its low tensile strength. Steel-concrete composite systems for buildings are composed of concrete components that interact with structural steel components within the same system. By their integral behaviour, these components give the required attributes of strength, stiffness and stability to the overall system. Composite members as individual elements of a system have been in use for a considerable number of years. They consist of composite beam, columns, trusses, encased or filled composite elements and steel deck reinforced composite slabs. These members are generally used in steel structures, and their development as composite members is based on utilizing the concrete that would normally be required for encased beam with different composite materials, or that would be required for reducing the concrete quantity. Also to improve the stability of elements present in the structure.

In structural engineering, composite construction exists when two different materials are bound together so strongly that they act together as a single unit from a structural point of view. When this occurs, it is called composite action. One common example involves steel beams supporting concrete floor slabs. If the beam is not connected firmly to the slab, then the slab transfers all of its weight to the beam and the slab contributes nothing to the load carrying capability of the beam. However, if the slab is connected positively to the beam with studs, then a portion of the slab can be assumed to act compositely with the beam. In effect, this composite creates a larger and stronger beam than would be provided by the steel beam alone. The structural engineer may calculate a transformed section as one step in analyzing the load carry capability of the composite beam.

\subsection{RESEARCH SIGNIFICANCE}

The primary objective of this work is to compare the flexural capacity of composite beam using 1. PVC, 2.Bamboo, 3.Steel.Very few literatures are available comparing encased beam with different materials. Therefore in this paper, experimental investigation on flexural capacity of different type of materials such as bamboo, steel, plastic for encased concrete structures.

Figure 1 details of the beam with composite material

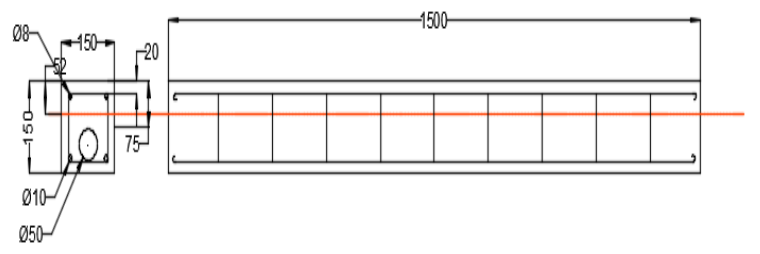

ALL DIMENSIONS ARE IN (mm)

Revised Manuscript Received on April 12, 2019.

S.Gowtham, Civil Engineering Department, Karunya Institute Of Technology And Sciences,(Deemed-to-be-University)Karunya Nagar, Coimbatore - 641 114. T.N, INDIA.

R. Mercy Shanthi, Civil Engineering Department, Karunya Institute Of Technology And Sciences, (Deemed-to-be-University) Karunya Nagar, Coimbatore - 641 114. T.N, INDIA.

M.Jemimahcarmichael, Civil Engineering Department, Karunya Institute Of Technology And Sciences, (Deemed-to-be-University) Karunya Nagar, Coimbatore - 641 114. T.N, INDIA. 


\begin{tabular}{|l|c|c|}
\hline & $\mathbf{( N / \mathbf { m m } ^ { \wedge } \mathbf { 2 }}$ & $\mathbf{p s i}$ \\
\hline $\begin{array}{l}\text { Modulus of } \\
\text { Elasticity(MOE) }\end{array}$ & 16,170 & $2.3^{*} 10^{\wedge} 6$ \\
\hline $\begin{array}{l}\text { Bending Strength, } \\
\mathrm{f}_{\mathrm{b}}\end{array}$ & 20.27 & 2940 \\
\hline $\begin{array}{l}\text { Compressive } \\
\text { Strength, } \mathrm{f}_{\mathrm{c}}\end{array}$ & 7.86 & 1140 \\
\hline Tensile Strength, $\mathrm{f}_{\mathrm{t}}$ & 14.96 & 2170 \\
\hline $\begin{array}{l}\text { Longitudinal Shear } \\
\text { Strength, } \mathrm{f}_{\mathrm{v}}\end{array}$ & 1.41 & 205 \\
\hline
\end{tabular}

Table 1Properties of bamboo

\begin{tabular}{|l|l|}
\hline \multicolumn{1}{|c|}{ Property } & Value \\
\hline Technical Name & Polyvinyl Chloride (PVC) \\
\hline Chemical Formula & $(\mathrm{C} 2 \mathrm{H} 3 \mathrm{Cl}) \mathrm{n}$ \\
\hline Melt Temperature & $\begin{array}{l}212-500^{\circ} \mathrm{F}\left(100-260^{\circ} \mathrm{C}\right) \\
* * *\end{array}$ \\
\hline $\begin{array}{l}\text { Heat Deflection } \\
\text { Temperature (HDT) }\end{array}$ & $92^{\circ} \mathrm{C}\left(198^{\circ} \mathrm{F}\right) * *$ \\
\hline \multirow{5}{*}{ Tensile Strength } & $\begin{array}{l}\text { Flexible PVC: } 6.9-25 \mathrm{MPa} \\
(1000-3625 \mathrm{PSI})\end{array}$ \\
\cline { 2 - 3 } & $\begin{array}{l}\text { Rigid PVC: } 34-62 \mathrm{MPa} \\
(4930-9000 \mathrm{PSI}) * *\end{array}$ \\
\hline Specific Gravity & $1.35-1.45$ \\
\hline
\end{tabular}

Table 2 Properties of pvc

\section{EXPERIMENTAL STUDY}

Six specimens of composite hollow beam are cast with bamboo tube (2nos), steel tube ( 2 nos), pvc tube (2nos) steel and concrete and two specimens of reinforced concrete.Table3. Shows the Reinforcement details of the beam and placing of composite material.And details of the beam specimens are shown. The reference beam was normal reinforced concrete with 4 nos of rebar. 2 no's $10 \mathrm{~mm}$ dia bar at bottom and 2no's of $8 \mathrm{~mm}$ dia bar at top Table 5 shows details of the composite sections used in the beam.

\begin{tabular}{|c|c|c|c|c|c|c|}
\hline \multirow[t]{2}{*}{$\begin{array}{l}\stackrel{0}{z} \\
\bar{n}\end{array}$} & \multicolumn{2}{|c|}{ 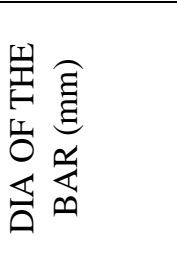 } & 气̂ & 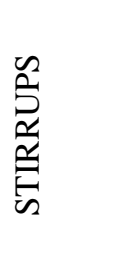 & 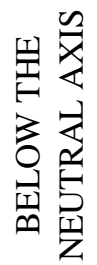 & 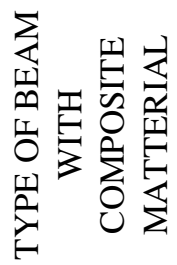 \\
\hline & oิ & $\begin{array}{l}\sum_{0} \\
0 \\
\\
0 \\
0\end{array}$ & & & & \\
\hline 1 & 8 & 10 & 2 & $\begin{array}{c}8 \mathrm{~mm} @ \\
150 \mathrm{~mm} \\
\mathrm{c} / \mathrm{c}\end{array}$ & $\begin{array}{c}52 \\
\mathrm{~mm}\end{array}$ & $\begin{array}{c}\text { PVC } \\
\text { HOLLOW } \\
\text { PIPE }\end{array}$ \\
\hline 2 & 8 & 10 & 2 & $\begin{array}{c}8 \mathrm{~mm} @ \\
150 \mathrm{~mm} \\
\mathrm{c} / \mathrm{c}\end{array}$ & $\begin{array}{c}52 \\
\mathrm{~mm}\end{array}$ & $\begin{array}{l}\text { BAMBOO } \\
\text { (WOOD) }\end{array}$ \\
\hline 3 & 8 & 10 & 2 & $\begin{array}{c}8 \mathrm{~mm} @ \\
150 \mathrm{~mm} \\
\mathrm{c} / \mathrm{c}\end{array}$ & $\begin{array}{c}52 \\
\mathrm{~mm}\end{array}$ & $\begin{array}{c}\text { STEEL } \\
\text { HOLLOW } \\
\text { SECTION }\end{array}$ \\
\hline
\end{tabular}

Table 3Reinforcement details of the beam \& placing of composite material

\section{TEST RESULTS AND DISSCUSSION}

Based on the result obtained, the load-deflection graphs for the four specimens vary in the load carrying capacity and also it has some difference in deflection. Beam with steel composite material have higher gradient compared with all other specimens. When the load was applied on the specimens, the graph start to show increasing in value for both load and deflection. The deflection of the specimen's increases directly proportional to the load applied. Once reaching the proportional limit, the graph tends to increase with a less steep gradient unit reached the ultimate flexural strength. Besides, the graph differs in the numerical value due to their different dimension and shape.

The flexural strength of the specimens which takes load carrying capacity of reference beam is $30 \mathrm{Mpa}$, plastic composite beam is $56.66 \mathrm{Mpa}$ bamboo composite beam is 33.33 Mpa steel composite beamis 93.33 Mpa. The load carrying differences are quite large between these four specimens, specimens which encased with the steel have the large load carrying capacity compared to the all three specimens, the plastic encased composite beam carrying high load compared to the reference and bamboo composite beam, comparing the reference and the bamboo encased composite beam load carrying is slightly higher than the reference beam. Also it is found that concrete used is lesser in bamboo encased compared to reference section.

\begin{tabular}{|c|c|c|c|c|c|c|}
\hline$\stackrel{0}{Z}$ & 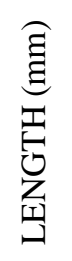 & 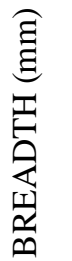 & 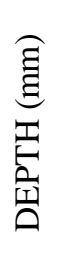 & 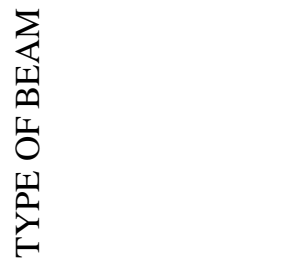 & \multicolumn{2}{|c|}{ 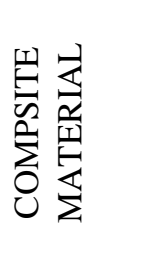 } \\
\hline 1 & $\begin{array}{c}150 \\
0\end{array}$ & 150 & 150 & $\begin{array}{c}\text { Reference } \\
\text { Beam(R.C.C) }\end{array}$ & $\begin{array}{l}\text { TK } \\
(\mathrm{m} \\
\mathrm{m})\end{array}$ & $\begin{array}{l}\text { DIA } \\
\text { of } \\
\text { the } \\
\text { pipe( } \\
\text { mm) }\end{array}$ \\
\hline 2 & $\begin{array}{c}150 \\
0\end{array}$ & 150 & 150 & $\begin{array}{l}\text { Composite Material } \\
\text { With PVC hollow } \\
\text { pipe }\end{array}$ & 2 & 50 \\
\hline 3 & $\begin{array}{c}150 \\
0\end{array}$ & 150 & 150 & $\begin{array}{l}\text { Composite Material } \\
\text { with Bamboo }\end{array}$ & 2 & 50 \\
\hline 4 & $\begin{array}{c}150 \\
0\end{array}$ & 150 & 150 & $\begin{array}{c}\text { Composite Material } \\
\text { with steel hollow } \\
\text { section }\end{array}$ & 2 & 50 \\
\hline
\end{tabular}

Table 4 Details Of The Beam and Composite Material

\begin{tabular}{|r|r|r|r|r|}
\hline & \multicolumn{4}{|c|}{ DEFLECTON (MM) } \\
\hline $\begin{array}{r}\text { LOAD } \\
\text { (TONNE) }\end{array}$ & REFERENCE & PLASTIC & BAMBOO & STEEL \\
\hline 0 & 0 & 0 & 0 & 0 \\
\hline 1 & 0 & 0 & 1 & 0 \\
\hline 2 & 2.9 & 0.7 & 3 & 0.8 \\
\hline 3 & 3.4 & 2.1 & 5.6 & 0.9 \\
\hline
\end{tabular}




\begin{tabular}{|r|r|r|r|r|}
\hline 4 & 6.7 & 3.3 & 8.4 & 1.2 \\
\hline 5 & & 4.6 & 19.5 & 1.7 \\
\hline 6 & & 5.7 & & 2 \\
\hline 7 & & 7 & & 2.6 \\
\hline 8 & & 8.6 & & 3.1 \\
\hline 9 & & & & 3.7 \\
\hline 10 & & & & 4.8 \\
\hline 11 & & & & 6.3 \\
\hline 12 & & & & 8.3 \\
\hline 13 & & & & 11 \\
\hline 14 & & & & 14 \\
\hline
\end{tabular}

Table 5Comparison of Load vsDeflectionfor Different Composite Materials

Figure 2 Deflection In Flexure Strength For Reference And Composite Beams

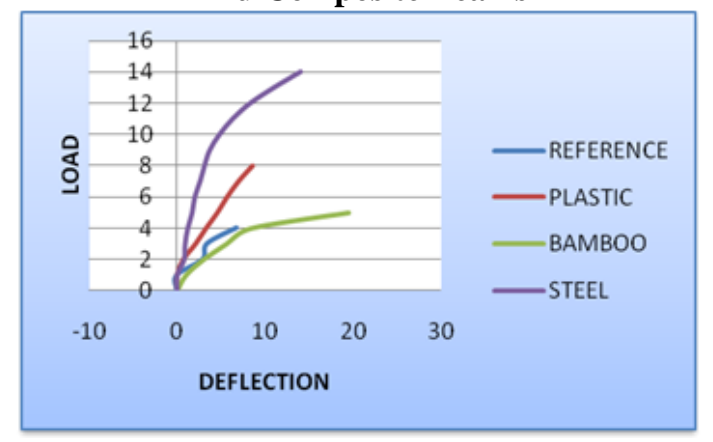

\section{CONCLUSION}

The results of experimental method show that, in addition to the reduction in the weight of the beam and the volume of concrete used, creating a hollow section in a reinforced concrete beam by inserting a Bamboo Tube, PVC, and Steel tube duringconstruction increased the strength of the beamsnoticeably.

Figure 3Failure form of composite beam and load setup

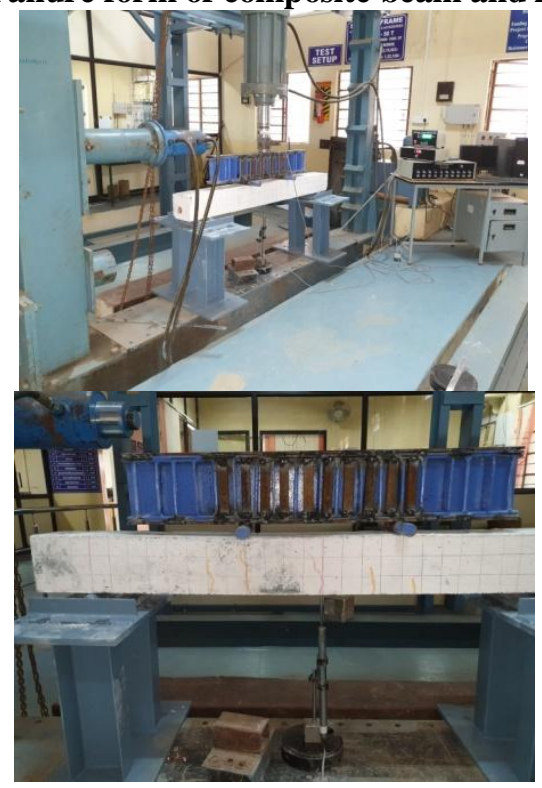

The experimental results showed as increase in strength of $50 \%$ in plastic, $20 \%$ in bamboo, and $71 \%$ in steel when compared to reference beam. A $71 \%$ increase in strength between the reference beam and the steel composite beam failing only in shear was attained using experimental test. It is obtained by comparing Load vs. Displacement graphs, of reference beams with different modes of failure with the corresponding composite beams, that the addition of the Hollow Bamboo Tube, PVC, and Steel Tube causes a considerable decrease in deflection of the beams. This improvement in structural properties achieved suggests that composite reinforced concrete bamboo elements may, in future, be used for improving the strength at an early stage in construction.

\section{REFERENCE}

1. Abdel-Sayed, G,Composite Cold-Formed Steel Concrete Structural Systems. Proceedings 6th International Specialty Conference on Cold-Formed Steel Structures, Rolla, Missouri, 1982 pp. 485-510.

2. ACI, Building Code Requirements for Structural Concrete (ACI 318M-08) and Commentary, Farmington Hills, MI., 2008.

3. Badalamenti, V., Campione, G., \&Mangiavillano, M. L. (2010). Simplified model for compressive behavior of concrete columns strengthened by steel angles and strips. Journal of Engineering Mechanics, 136(2), 230-238.

4. Duricová, A.; Rovňák, M.: Design of Steel -Concrete Structures in Accordance with EN 1994-1-1, Bratislava, VEDA SAV, 2008, ISBN 978-80-224-1022-9.

5. Elghazouli, A.Y. and Treadway, J., "Inelastic behaviour of composite members under combined bending and axial loading", Journal of Constructional Steel Research 64, 10081019, 2008

6. Gara F, Ranzi G and Leoni G (2010), "Short-and long-term analytical solutions for composite beams with partial interaction and shear-lag effects", International Journal of Steel Structures, Vol. 10, No. 4, pp. 359-372.

7. Hsu, C. T. T., Punurai, S, Punurai, W. and Majdi, Y. New Composite Beams having Coldformed Steel Joists and Concrete Slab. Engineering Structures, 71, 2014, pp. 187-200.

8. Hassan O. Reinforced Concrete design. Presented at Swansea University. Swansea, 2013.

9. IS 456 -2000, "Code of Practice for Plain and Reinforced Concrete," Bureau of Indian Standards, New Delhi.

10. IS 11384-1985, "Composite Construction in Structural Steel and Concrete," Bureau of Indian standards, New Delhi.

11. N.E. Shanmugam, B. Lakshmi, State of the art report on steelconcrete composite columns, J. Constr. Steel Res. 57 (2001) 1041-1080.

12. S Yehia and G Kashwani, "Performance of structures exposed to extreme high temperature-An overview", Open Journal of Civil Engineering, Vol 3, 154-161,2013.

13. http://www.sciencedirect.com/science/article/pii/S187770581 7304848

14. http://www.iaeme.com/IJCIET/index.asp 